\title{
Improving methods for epidemiological control of canine visceral leishmaniasis based on a mathematical model. Impact on the incidence of the canine and human disease
}

\author{
CLARISA B. PALATNIK-DE-SOUSA ${ }^{1}$, LEOPOLDINA M. BATISTA-DE-MELO ${ }^{2}$, \\ GULNARA P. BORJA-CABRERA ${ }^{1}$, MARCOS PALATNIK ${ }^{3}$ \\ and CARLILE C. LAVOR ${ }^{4}$ \\ ${ }^{1}$ Instituto de Microbiologia, "Prof. Paulo de Góes", Universidade Federal do Rio de Janeiro (UFRJ), CCS \\ Cidade Universitária, Ilha do Fundão, Cx. Postal 68040, 21941-590 Rio de Janeiro, RJ, Brasil \\ ${ }^{2}$ Centro de Controle de Zoonoses, Av. das Fronteiras, s/n, Conjunto Santa Catarina, \\ 59422-630 Rio Grande do Norte, RN, Brasil \\ ${ }^{3}$ Faculdade de Medicina-Hospital Universitário "Clementino Fraga-Filho" \\ Universidade Federal do Rio de Janeiro, Ilha do Fundão, 21941-590 Rio de Janeiro, RJ, Brasil \\ ${ }^{4}$ Instituto de Matemática e Estatística, Universidade do Estado do Rio de Janeiro (IME-UERJ) \\ Rua São Francisco Xavier, 524 B1.1 B $6^{\circ}$ andar, 20559-900 Rio de Janeiro, RJ, Brasil \\ Manuscript received on October 2, 2003; accepted for publication on March 3, 2004; \\ presented by Lucia Mendonça Previato
}

\begin{abstract}
The mathematical model described by Dye (1996) condemned the epidemiological canine visceral leishmaniasis control campaign, considering it non-efficient. Using this model, we mathematically demonstrate that the control is not efficient, only at low $\kappa$ values (rate at which latent and infectious dogs are lost by the destruction program) which match the canine seropositivity observed in the field by the immunofluorescency (IF) blood eluates analysis. With higher $\mathrm{k}$ values, corresponding to IF $(\kappa=0.07)$ or ELISA $(\kappa=0.25)$ results in sera samples, the number of infectious dogs declines to a $R_{O}=1$ or $R_{O}=0$, respectively, interrupting the transmission and the advancement of epidemics. We also experimentally demonstrate that the dog removal, following the results of IF of sera, instead of eluates lead to a $57 \%(p<0.005)$ decrease in canine cases and $87.5 \%(p<0.005)$ in human cases. Our mathematical and experimental results indicate that the control campaign become more efficient by enhancing the sensitivity of the diagnostic assay.
\end{abstract}

Key words: canine visceral leishmaniasis, epidemiological control, immunofluorescent assay.

\section{INTRODUCTION}

Human visceral leishmaniasis or kala-azar is, in the Mediterranean and in the New World, a re-emergent canid zoonoses (Tesh 1995). The parasite is exposed on the skin of dogs and wild canids and transferred to human through the byte of the

Correspondence to: Prof. Clarisa B. Palatnik-de-Sousa

E-mail: clarisaps@infolink.com.br / immgcpa@micro.ufrj.br specific sandflies. The present epidemiological control, as recommended by the World Health Organization, involves the treatment of human cases, the insecticide vector control and the removal for sacrifice of the Leishmania-seropositive dogs (Tesh 1995). In Brazil, the impact of the control campaign has been either supported (Magalhães et al. 1980, Ashford et al. 1998, Jeronimo et al. 2000) or contested (Di- 
etze et al. 1997, Furtado Vieira and Coelho 1998), mainly for being too laborious and of doubty efficacy, probably due to the low sensitivity of the diagnostic methods (Machado Braga et al. 1998, BorjaCabrera et al. 1999, Palatnik-de-Sousa et al. 2001) and delay in removal of infectious dogs (Machado Braga et al. 1998). The control campaign official data (Furtado Vieira and Coelho 1998), shows however, that the increase in removal of seropositive dogs led to the maintenance of the human annual cases at basal levels (Palatnik-de-Sousa et al. 2001).

Dye (1996), described a mathematical model for the transmission of zoonotic visceral leishmaniasis (ZVL) and concluded that the dog removal would not have impact on the decrease of the canine infectious population. A human or canine vaccine or insecticide control instead, would be efficient tools. In the mathematical model used by Dye (1996), a relatively low value was attributed to the $\kappa$ parameter (rate at which latent and infectious dogs are lost and susceptible replaced by the control program), probably based on the low sensitivity of the diagnosis performed by immunofluorescency (IF) in blood eluates, and to the assumption that infected dogs removed by the control program are immediately substituted by susceptible animals (Palatnikde-Sousa 2002).

Several variables could be responsible indeed, for the controversial low efficacy of the control program. The IF test itself, although considered as a gold standard in studies of clinical and parasitologically characterized human or dog samples, shows lower sensitivity and specificity, in field studies. Samples are mostly analyzed as eluates of blood drops adsorbed in filter paper. Usually, results are obtained from pooled samples and there is a long delay between their collection and removal of dogs (Machado Braga et al. 1998).

In the present investigation, we analyzed Dye's model with variation of the $\kappa$ values, according the potency of more sensitive diagnostic methods and demonstrated, mathematically and experimentally, the great impact on reduction of canine infectious dog population and on human disease by the enhancement of sensitivity of diagnostic methods.

\section{MATERIALS AND METHODS}

Analysis of Infectious Dog Population in the Field. Variation of the Efficacy of the Control Program. Calculation of the $R_{O}$ Values in the Mathematical Model of ZVL

To model the dynamics of the transmission of visceral leishmaniasis between dogs in the field we used the following differential equation system previously described by Dye (1996):

$$
\begin{aligned}
d S / d t= & \alpha_{D} \beta_{D} D+\kappa(L+I) \\
& -C_{D} I(S / D)-\delta S \\
d L / d t= & C_{D} I(S / D)-(\sigma+\delta+\kappa) L \\
d I / d t= & \sigma L-(\delta+\kappa) I \\
d R / d t= & \left(1-\alpha_{D}\right) \beta_{D} D+\rho I-\delta R
\end{aligned}
$$

The parameters were those described by Dye (1996) with variation of $\alpha_{D}$ and $\kappa$ values according to Table I. The parameter $\beta_{D}$, the birth rate of dogs, was obtained considering two annual deliveries of an average of $5 \mathrm{dogs}$ each, distributed along the 365 days of a year $(10 / 365=0.027)$. We analyzed the variation of the infectious dog population with predetermined $\kappa$ values $(0 ; 0.02 ; 0.25 ; 0.5 ; 1.0)$ for $\alpha_{D}=0.02$ or $\alpha_{D}=0.25$.

Furthermore, according to Dye's model (1996) we needed to assume initial values for the distribution of population (Table II). We assumed that on Dye's model (1996), the number of susceptible dogs was 50\% and that always, the infected dogs, sacrificed by the control campaign are substituted by susceptible puppies. On the other hand, the values we attributed to the S, I and $\mathrm{L}$ categories in this study (Table II), are close to the mean averages values obtained by different field studies, performed in Brazil by different authors, using different serological ELISA assays with different antigen preparations (Paranhos-Silva et al. 1996, Ashford et al. 1998, Dietze et al. 1997, Borja-Cabrera et al. 1999). All these studies gave close related values of canine 


\section{TABLE I}

Definition of variables and parameters used in the Model of ZVL.

\begin{tabular}{l|l|l}
\hline $\mathrm{S}$ & Number of susceptible dogs & \\
\hline $\mathrm{L}$ & Number of latent dogs & \\
\hline $\mathrm{I}$ & Number of infectious dogs & \\
\hline $\mathrm{R}$ & Number of resistant dogs & \\
\hline $\mathrm{D}$ & Number of dogs (S+L+I+R) & \\
\hline $\mathrm{C}_{\mathrm{D}}$ & $\begin{array}{c}\text { Vectorial capacity of the sandfly population } \\
\text { transmitting infection between dogs }\end{array}$ & \\
\hline$\alpha_{\mathrm{D}}$ & Proportion of dogs born susceptible to ZVL & $0.02 ; 0.25 ; 0.5 ; 1$ \\
\hline$\beta_{\mathrm{D}}$ & Birth rate of dogs & 0.027 \\
\hline$\sigma$ & Rate at which latently infected dogs become infectious & 0.005 \\
\hline$\delta$ & The average mortality rate of dogs & 0.00167 \\
\hline$\epsilon$ & Incidence rate of dog infection & 0.015 \\
\hline$\kappa$ & Rate at which latent and infectious dogs are lost, and & \\
\hline $\mathrm{R}_{\mathrm{o}}$ & Base case reproduction number & $0 ; 0.02 ; 0.25 ; 0.5 ; 1$ \\
\hline
\end{tabular}

TABLE II

Population composition in the mathematical model for ZVL.

\begin{tabular}{c|l|c|c}
\hline Population & \multicolumn{1}{|c|}{ Categories } & $\begin{array}{c}\text { Initial number } \\
\text { and proportions } \\
\text { Dye (1996) }\end{array}$ & $\begin{array}{c}\text { Initial number } \\
\text { and proportions, } \\
\text { this investigation }\end{array}$ \\
\hline $\mathrm{N}$ & Initial dog population number & $\mathrm{N}=2000$ & $\mathrm{~N}=2000$ \\
\hline PS & $\begin{array}{c}\text { Proportion of the susceptible dogs. } \\
\text { These are the dogs acquiring infection } \\
\text { after the sandfly byte. }\end{array}$ & 0.5 & 0.15 \\
\hline PL & $\begin{array}{l}\text { Proportion of latent dogs: susceptible, } \\
\text { infected, still asymptomatic and } \\
\text { non-infectious dogs. }\end{array}$ & 0.125 & 0.05 \\
\hline PI & Proportion of infectious dogs. & 0.125 & 0.10 \\
\hline PR & $\begin{array}{c}\text { Proportion of resistant dogs. Infected, } \\
\text { asymptomatic and non-infectious } \\
\text { to sandflies }\end{array}$ & & \\
\hline
\end{tabular}


seroprevalences: $23.5 \%$ in Natal (Borja-Cabrera et al. 1999); 23.5\% (Paranhos-Silva et al. 1996) and 28.5\% (Ashford et al. 1998) in Bahia and 30.5\% in Espirito Santo (Dietze et al. 1997). The mean average of them was $25.0 \% \pm 3.19$, suggesting that this was the actual proportion of susceptible, latent and infectious dogs, responsible for ZVL transmission in endemic areas submitted to the control campaign. Therefore, in this investigation we compared the calculation of $\kappa$ values, using two different compositions of population distribution (Table II).

For the determination of the $R_{o}$ values, we used the formula developed by Dye (1996) as follows:

$$
R_{o}=\left(C D \alpha_{D} \sigma\right) /(\delta+\kappa)(\sigma+\delta+\kappa)
$$

We calculated the $R_{O}$ values with variation of $\kappa$ values from 0.02 to 0.25 .

For all the above-described equations, calculations were performed using the Maple Software.

\section{Effect of the Use of Sera Instead of Blood} ELUATES IN THE IMMUNOFLUORESCENCY AsSAY FOR Canine Control in Jardim Progresso,

\section{NATAL, RN}

Canine serological screenings for the presence of anti-Leishmania chagasi antibodies were annually performed (1999-2003) in Jardim Progresso, Natal, Rio Grande do Norte, a populated urban area of $\mathrm{Na}-$ tal, of low socieconomical status and high human immigration rate, where human and canine kalaazar are highly endemic. A total of 2184 samples of domiciliary dogs were collected by our personnel. These animals were fed ad libitum and maintained in each own residence during the whole project. Clinical symptoms of kala-azar (loss of weight, cachexia, allopecy, onycogryphosis, apathy, ulcerative skin lesions) were identified and recorded for each animal. From 1999 to the first semester of 2001, a drop of blood of the ear edge was obtained after puncture with a sterile disposable needle and collected (1099 samples) on squares of filter paper, dried and stored at $-20^{\circ} \mathrm{C}$ until analysis. Antibodies were eluted from filter paper with PBS. Dilutions of eluates were incubated with $L$. (L.) cha- gasi promastigotes (Biomanguinhos, Fundação Oswaldo Cruz, Rio de Janeiro, Brazil) platted on slides, dried, incubated with diluted dog sera and further treated with a fluoresceinated goat anti-dog IgGspecific conjugate (Biomanguinhos, Fundação Oswaldo Cruz, Rio de Janeiro, Brazil) in a 1:40 dilution (Camargo 1966). Reactions were considered positive if fluorescent at a 1:40 dilution. This is the usual limit value for diagnosis of leishmaniasis in immunofluorescence assays in field control in Brazil considered as reference by the Brazilian National Foundation for Health (FUNASA). Starting from the second semester of 2001 and until 2003, sera samples were collected from cephalic vein blood, resuspended in glycerol (1:1) and analyzed by immunofluorescency. Blood collection was performed on the immobilized animals, after local assepsy with no need of anesthetic procedure. A comparison of sensitivities was performed with the samples collected during the second semester of 2001, using immunofluorescency of blood eluates and sera, and FML-ELISA assay in 1:100 diluted serum samples (Borja-Cabrera et al. 1999). Samples for the FMLELISA assay were analyzed in triplicates. The reaction was developed as described elsewhere (Palatnik-de-Sousa et al. 1995) and the absorbance values were recorded at $492 \eta \mathrm{m}$. The cut-off of the method for the analysis of canine sera was determined according to the Youden test (reviewed by Palatnik-de-Sousa et al. 1995).

\section{Statistical Analysis}

The $\chi^{2}$ test was used for comparison of proportions. Correlation coefficient analysis between human kala-azar incidence and total dog population or human and canine incidence of the disease was determined on a Pearson bivariate or Spearman's (nonparametric), two-tailed test of significance (SPSS).

\section{RESULTS}

Variation of the Infectious Dog Population IN THE Field AcCording to the $\kappa$ VAlues

The $\kappa$ value represents the power of the control campaign on the removal of infectious dogs. The results 


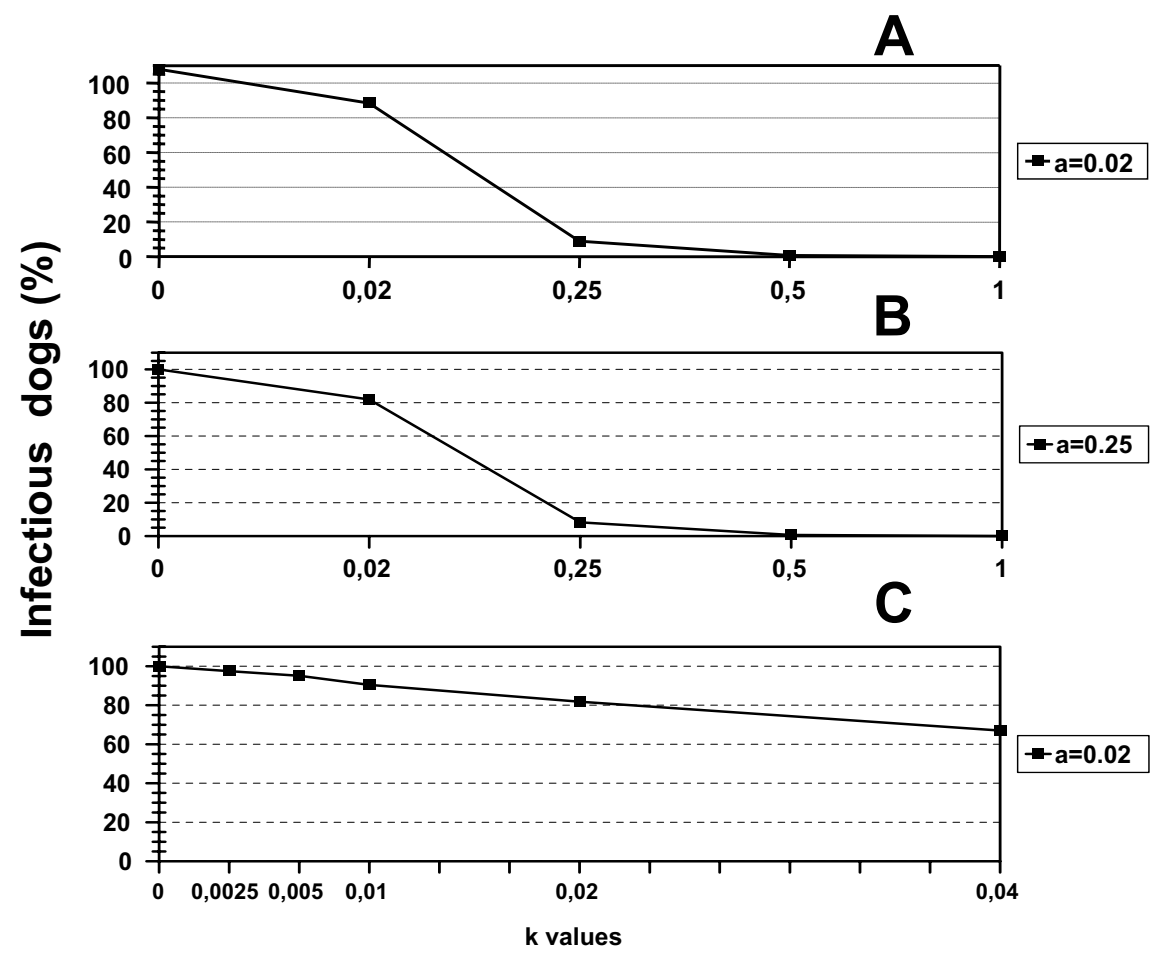

Fig. 1 - Variation of the infectious dog population in the field according to the $\kappa$ values. The $\kappa$ value represents the power of the control campaign ( $x$ axis) on the removal of infectious dogs ( $y$ axis). Considering an initial number of $2000 \mathrm{dogs}, 30 \%$ of them already infected, the effect of $\kappa$ value is analyzed, using an $\alpha_{D}=0.02$ (Figure 1A), and an $\alpha_{D}=0.25$ (Figure 1B). We also tested the model using the initial population composition of susceptible dogs $(50 \%)$ at $\alpha_{D}=0.02$ (Figure 1C).

of the analysis of variation of the $\kappa$ values is summarized in Figure 1. Considering an initial number of $2000 \mathrm{dogs}, 30 \%$ of them already infected (S + I + L) (Table II), using a $\alpha_{D}=0.02$, the canine control program shows almost no impact in the range of $\kappa=$ 0 to 0.02 (Figure 1A). Indeed, $88.4 \%$ of infectious dogs remain in the field when the control program removes a maximum of $2 \%$ of seropositive dogs. The impact of the control however, shows a pronounced decrease in infectious dogs with $\kappa$ values slightly higher than 0.02 and only $8.9 \%$ of infectious dogs remain in the field using a $\kappa=0.25$ (Figure $1 \mathrm{~A}$ ). Very similar results were obtained using a $\alpha_{D}=0.25$, indicating that the increase in the number of dogs born susceptible does not interfere in the system (Figure 1B). We also tested the model using the initial population composition we presumed as the previous used by Dye (1996), considering higher number of susceptible dogs (50\%) (Table II) and no significant variation was seen on the decline of the infectious population (Figure 1C). Indeed, while very low impact on infectious dog population is seen with $\kappa$ values ranging from 0 to 0.02 (97.5 to $81.8 \%$ ) a significant reduction of infectious dogs starts from $\kappa=0.04(67 \%)$.

\section{VARIATION OF $R_{O}$ According to $\kappa$ VAlues}

$R_{o}$, the basic case reproduction number, is the number that defines the onset of the epidemic. The interruption of the infection cycle and of the epidemics would occur at $R_{O} \leq 1$ (Dye 1996). We analyzed the variation of $R_{o}$ in relation to $\kappa$ values. The results are summarized in Figure 2. When the control campaign removes only $2 \%$ of the infectious dogs 
( $\kappa$ values ranging from 0 to 0.02 ), the epidemic is active $\left(R_{O}=10\right)$. However, a strong decline in the $R_{O}$ values is seen with $\kappa$ values starting from 0.02 . The $R_{o}=0$ if the control campaign removes $25 \%$ of the infectious dogs. However, the removal of $7 \%$ of the infectious dog population $(\kappa=0.07)$ is enough to interrupt the infectious cycle in nature $\left(R_{O}=1\right)$, finishing the epidemics.

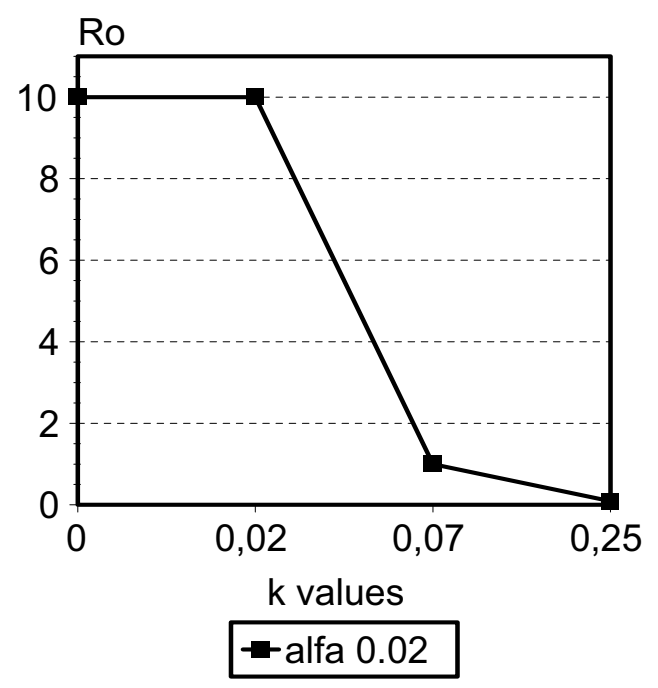

Fig. 2 - Variation of $R_{O}$ according to $\kappa$ values. $R_{O}$ is the number that defines the onset of the epidemic. The interruption of the infection cycle and of the epidemics would occur at $R_{O} \leq 1$ (Dye 1996). We analyzed the variation of $R_{O}$ ( $y$ axis) in relation to $\kappa$ values ( $x$ axis).

\section{SERa Instead of Blood Eluates for IMMUNOFLUORESCENT ASSAY. IMPACT ON HUMAN Kala-AZAR INCIDENCE}

A comparison of percent of seropositivities was performed on the 417 samples collected in two epidemiological enquires at Jardim Progresso, Natal, RN, during the second semester of 2001. The samples were analyzed for their positivities in immunofluorescency of blood eluates and sera and in FMLELISA of sera samples. The results are summarized in Table III. The immunofluorescency was less sensitive in eluates (mean average $=8.7 \%$ ) than in sera samples (mean average $=12.9 \%$ ). The highest pos- itivities were found in the sera analysis performed with the FML-ELISA assay (28.8\%). Indeed, positivities in the FML-ELISA assay were significantly higher than those disclosed by immunofluorescency in eluates $(p<0.05)$ and in sera $(p<0.005)$. The differences between positivities in eluates or sera analyzed by immunofluorescency, however were not significant $(p>0.05)$.

Furthermore, the canine removal for sacrifice, in Jardim Progresso, Natal, RN, was performed according the results of immunofluorescency in blood eluates (Table IV) (from 1999 to the first semester of 2001) and to the results of immunofluorescency in sera samples (from the second semester of 2001 to 2003). The number of canine cases of disease showed a decline from 2001 (54) to 2002 (1) (Table IV). This decrease was however not significant, neither using for comparison the 2001 seropositivities in eluates $\left(36 / 417 \times 1 / 36 ; \chi^{2}=1.550 ; p>0.05\right)$ (Tables III and IV) or in sera $\left(54 / 417 \times 1 / 36 ; \chi^{2}=\right.$ $3.130 ; p>0.05)$. This fact might be related to the small area covered by the control campaign in 2002, or indicates that the effect of dog removal, according to a higher $\kappa$ value (immunofluorescency in sera) requires a longer period to achieve significance.

On the other hand, when comparing the canine incidence of 2001 to that of 2003, a strong decline is noted. Indeed, a significant reduction $(p<0.005)$ of $57 \%$ of canine cases was observed.

Concomitantly to the use of immunofluorescency in sera samples, the number of human kalaazar cases in the area were reduced (Table IV). Indeed, an $87.5 \%$ of significant reduction was observed either from 2001 to $2002\left(\chi^{2}=7.157\right.$, $p<0.001)$ or from 2001 to $2003\left(\chi^{2}=8.570\right.$; $p<0.005)$.

Noteworthy, Jardim Progresso shows very rapid increase in human population during the studied period $(30.7 \%)$. This fact could be responsible for a dilution of the kala-azar cases among the normal human population, giving some bias in the interpretation of the human incidence decline. However, the susceptible dog population suffered the same magnitude increase (34\%) in the same period, indi- 
TABLE III

Comparison of seropositivities in immunofluorescency of blood eluates, sera and FMLELISA sera assay.

\begin{tabular}{c|c|c|c|c|c|c|c|c}
\hline Year & $\%$ area & $\begin{array}{c}\text { Total canine } \\
\text { samples }\end{array}$ & $\begin{array}{c}\text { Positive } \\
\text { IF-E }\end{array}$ & $\%$ & $\begin{array}{c}\text { Positive } \\
\text { IF-serum }\end{array}$ & $\%$ & $\begin{array}{c}\text { Positive } \\
\text { FMLELISA }\end{array}$ & $\%$ \\
\hline \multirow{2}{*}{2001} & 100 & 198 & 19 & 9.6 & 30 & 15.0 & 56 & 28.0 \\
\cline { 2 - 10 } & 100 & 219 & 17 & 7.8 & 24 & 10.9 & 65 & 29.7 \\
\hline Total & 100 & 417 & 36 & & 54 & & 121 & \\
\hline Mean & & & & 8.7 & & 12.9 & & 28.8 \\
\hline
\end{tabular}

TABLE IV

Effect of the use of immunofluorescency in blood eluates or sera samples for the epidemiological control of ZVL in Jardim Progresso, Natal, RN.

\begin{tabular}{|c|c|c|c|c|c|c|c|c|}
\hline Year & $\%$ area & $\begin{array}{c}\text { Total canine } \\
\text { samples }\end{array}$ & $\begin{array}{c}\text { Positive } \\
\text { samples } \\
\text { (incidence) }\end{array}$ & $\begin{array}{c}\text { Incidence } \\
(\%)\end{array}$ & IF & $\begin{array}{l}\text { Human } \\
\text { kala-azar }\end{array}$ & $\begin{array}{c}\text { Total } \\
\text { humans }\end{array}$ & $\begin{array}{c}\text { Incidence } \\
\% \circ\end{array}$ \\
\hline 1999 & 100 & 351 & 27 & 7.7 & Eluates & 10 & 7744 & 1.29 \\
\hline 2000 & 100 & 358 & 08 & 2.2 & Eluates & 07 & 8644 & 0.81 \\
\hline \multirow[t]{2}{*}{2001} & 100 & 390 & 11 & 2.8 & Eluates & 08 & 9972 & 0.80 \\
\hline & 100 & 417 & 54 & 12.9 & Sera & & & \\
\hline 2002 & Restricted $*$ & 36 & 1 & 2.7 & Sera & 01 & 12396 & 0.08 \\
\hline 2003 & 100 & 632 & 31 & 4.9 & Sera & 01 & 14396 & 0.07 \\
\hline
\end{tabular}

*In 2002 following the Ministry of Health recommendations, the serological enquire was only performed in a $300 \mathrm{~m}^{2}$ area around the finding of a human kala-azar case.

cating a correlated increase of Leishmania reservoir. Therefore, the responsible for the decline of human and canine incidence of kala-azar was the increase of $\kappa$ values of the control campaign by changing the use of blood eluates for sera samples in immunofluorescent assay.

\section{DISCUSSION}

In the present investigation we meant to test Dye's model (1996) by studying the impact of the variation of $\kappa$ values on the reduction of the infectious dog population in the field, as a predictive tool for the possible improvement of the control campaign efficacy. We observed that using either an $\alpha_{D}=0.02$ or $\alpha_{D}=0.25$, the canine control program shows al- most no impact at low $\kappa$ values (2\%) that represent the usual value for canine seroprevalence disclosed in many Brazilian endemic areas, where immunofluorescency of blood eluates is used as standard diagnostic test (Borja-Cabrera et al. 1999, da Silva et al. 2001). The impact of the control however, shows a pronounced increase at higher $\kappa$ values, such as $25 \%$ which would represent the power of control campaign performed following the results of ELISA, as disclosed in different Brazilian regions (ParanhosSilva et al. 1996, Dietze et al. 1997, Ashford et al. 1998, Borja-Cabrera et al. 1999). The results of the mathematical model indicated that the use of an ELISA method as the standard test for removal of seropositive dogs from endemic areas, would com- 
pletely reduce the number of infectious dogs in the field having possible impact on the human incidence of the disease.

Furthermore, the $R_{o}=1$ when the control campaign removes $7 \%$ of the infectious dogs and $R_{o}=0$ if $25 \%$ of removal occurs. This means that according to the mathematical model (Dye 1996), an effective dog control campaign would occur with the optimization of the sensitivity of the serological assay used for control. While the use of immunofluorescence in blood eluates ( $2 \%$ ) would not be useful, the use of immunofluorescence in sera samples (78\%) (Evans et al. 1990 and this investigation) or ELISA assays (25\%) (Paranhos-Silva et al. 1996, Dietze et al. 1997, Ashford et al. 1998, BorjaCabrera et al. 1999) would guarantee an efficient control.

With the aim of assaying this hypothesis in the field conditions, we initially comparatively analyzed the canine visceral leishmaniasis prevalence in Jardim Progresso, an endemic area for canine and human kala-azar. Our analysis disclosed that the immunofluorescency of blood eluates was less sensitive than that of sera samples, while the highest positivities were found in the sera analysis performed with the FML-ELISA assay (8.7, 12.0 and 28.8\%, respectively). IF-sensitivity was also lower, if performed in eluates than in sera obtained from other reported field assays: 6.7 and 9.1\% in São Gonçalo do Amarante, RN (Borja-Cabrera et al. 1999) and 8 and $17 \%$ in Brotas, Ceará (Evans et al. 1990). Sensitivity was also higher in dog sera clinical samples (100\%) obtained from Araçatuba, SP, than in eluates $(p<0.005)$ transported either at room temperature (67.2\%) or at $4{ }^{\circ} \mathrm{C}(61.5 \%)$ (Borja-Cabrera 2002).

According to this information, we experimentally compared the removal of dogs performed following the results of immunofluorescency in blood eluates or in sera samples. The use of sera samples instead of eluates lead to a $57 \%$ and $87.5 \%$ of significant reduction, in canine cases and human cases of the disease, respectively. As predicted by the mathematical model then, the increase of $\kappa$ values of the control campaign by changing the use of blood eluates for sera samples had a strong impact on the decline of the disease incidence. The use of an ELISA assay for the canine control would probably reduce the human cases to zero. Ashford et al. (1998) analyzed the impact of canine control in two neighborhoods monitored by an ELISA assay. Only in the intervention area, removal of seropositive dogs was performed. A significant reduction of canine seroprevalence (36 to $6 \%, p<0.001$ ) and human incidence of disease (10 to 2 pediatric annual cases, $p<0.01$ ) was observed in the intervention area, while canine seroprevalence oscillated from 24-28\% with no change in mean average of annual human cases (6 to 7) in the control area with no removal.

Machado Braga et al. (1998), had already shown that sensitivity of the diagnostic test and the delay in the removal of dogs by the control program might be critical in the lack of success of the program. In their investigation, when control was performed according the IF-FUNASA results the decrease in seroprevalence was $9 \%$ while if done following the ELISA results reduction was significantly greater $(27 \% ; p=0.0015)$.

As we previously hypothesized (Palatnikde-Sousa 2002), the epidemiological canine control for visceral leishmaniasis might be feasible and effective, having impact on both the reduction of canine and human incidence of the disease. In this investigation, our results raised from the mathematical model and experimental field assays confirm that this might be easily performed by using sera samples instead of blood eluates, enhancing sensitivity and increasing the $\kappa$ value. Contesting this concept, Dye's model analysis (1996), concluded that the control campaign would not have impact on the reduction of the canine or human incidence. Dye's work assumed a maximum of 0.02 for $k$ value that matches the frequent values of canine seroprevalences described in Brazil (Borja-Cabrera et al. 1999, da Silva et al. 2001). However, in a recent work, the same group (Courtenay et al. 2002) reviewed their previous model (Dye 1996) concluding that only a high-sensitive test (ELISA) with no time 
delay will result in a sustained reduction of the proportion of infectious dogs to near zero. Interestingly, they got to this conclusion using the parameters values raised from the same field experiments referred in the original model (Dye 1996).

Recent investigations disclosed that the IgG1 subtype of immunoglobulin is predominant or increasing in the severe canine kala-azar (Solano-Gallego et al. 2001, Santana et al. 2002, Mendes et al. 2003, Nieto et al. 1999). The use of anti-IgG1 conjugates in diagnostic and prognostic serological assays used for canine control (Badaró et al. 1997, Borja-Cabrera et al. 1999) might give an enhanced impact on the reduction of the incidence of the disease.

The present epidemiological control for visceral leishmaniasis, as recommended by the World Health Organization, involves not only the treatment of human cases and the removal for sacrifice of the Leishmania-seropositive dogs but the insecticide vector control, as well (Tesh 1995). Since in the present investigation we focused our study on the impact of the sensitivity of diagnostic methods for canine control one must question whether any fluctuation in vector population density along the time would be responsible for the detected reduction in canine and human incidence of the disease. Although the vector population was not investigated, its actual presence is confirmed by the effective transmission of the disease. The density of phlebotomines however, would not decline during the period and could only be maintained or increased since the insecticide vector control in Jardim Progresso was interrupted, for reasons not related to this investigation, from the beginning of 1999 until 2004.

In this work, we experimentally demonstrate that: the use of serum instead of blood eluates enhances the $\kappa$ value through the increase of immunofluorescent sensitivity, reducing significantly the human and canine incidence of kala-azar in the field. Our mathematical model indicates that the use of an ELISA method would give even better results. In conclusion, our mathematical model and experi- mental results confirm that the methods for removal of seropositive dogs might be easily improved and that they represent efficient tools for the epidemiological control of human and canine kala-azar transmission.

\section{ACKNOWLEDGMENTS}

This study received financial support from: National Council for Scientific and Technological Development (CNPQ); MCT/PRONEX (Brazilian Ministry of Science and Technology); “José Bonifácio" University Foundation of the Federal University of Rio de Janeiro (FUJB-UFRJ), Rio de Janeiro State Research Foundation (FAPERJ), Council for Graduate Studies-UFRJ (CEPG-UFRJ), Brazil. Zoonoses Control Center (CCZ), Natal, RN.

\section{RESUMO}

O modelo matemático descrito por Dye (1996) condenava a campanha de controle do calazar canino por considerála ineficaz. Usando esse modelo, demonstramos matematicamente que a ineficácia somente ocorre com valores baixos de $\kappa$ (índice de remoção de cães infecciosos pela campanha de controle), que coincide com os valores de soropositividade detectados no campo, pelo método de imunofluorescência (IF) em eluatos. Aplicando valores maiores de $\kappa$, o controle se tornaria eficaz: valores de $\mathrm{k}$ correspondentes a IF $(\kappa=0.07)$ ou ELISA em soros $(\kappa=0.25)$ diminuiriam o numero de cães infecciosos, levando o valor de $R_{O}$ a 1 ou 0 respectivamente, impedindo com isso a transmissão e o avanço da epidemia. Demonstramos experimentalmente que a remoção de cães conforme os resultados de IF nos soros em lugar de eluatos diminuiu $57 \%$ dos casos caninos $(p<0.005)$ e de $87.5 \%$ dos casos humanos $(p<0.005)$. Os nossos resultados, demonstram que a campanha de controle se torna eficaz aumentando a sensibilidade do método diagnóstico.

Palavras-chave: leishmaniose visceral canina, controle epidemiológico, método de imunofluorescência. 


\section{REFERENCES}

AshFord DA, DAVID JR, Freire M, DAVID R, SHERlock I, Eulálio MC, Pedral SAMPaio D ANd Badaró R. 1998. Studies on control of visceral leishmaniasis: impact of dog control on canine and human visceral leishmaniasis in Jacobina, Bahia, Brazil. Am J Trop Med Hyg 59: 53-57.

Badaró R, Chun P, Nakatani M, Burns J, Skeiky Y, Houghton R, Arias J, Monteiro P, Genaro O AND REED SG. 1997. TRALd = a rapid test specific for serodiagnosis of visceral leishmaniasis. Acta Parasitol Turcica 21: 94.

BorJa-Cabrera GP. 2002. Análise do potencial diagnóstico, prognóstico e imunoprotetor do antígeno FML (Ligante de Fucose Manose) de Leishmania (L.) donovani, no calazar canino experimental e de área endêmica. PhD Thesis. Post-Graduate Program in Experimental Pahotology. Federal Fluminense University. Niteroi. Rio de Janeiro, Brasil.

Borja-Cabrera GP, da Silva VO, da Costa RT, Barbosa Reis A, Mayrink W, Genaro O and PalatNIK-DE-SousA CB. 1999. The FML-ELISA assay in diagnosis and prognosis of canine visceral leishmaniasis. Am J Trop Med Hyg 61: 296-301.

Camargo ME. 1966. Fluorescent antibody test for the serodiagnosis of American trypanosomiasis. Technical modification employing preserved culture forms of Trypanosoma cruzi in a slide test. Rev Inst Med Trop São Paulo 8: 224-227.

Courtenay O, Quinnell RJ, Garcez LM, Shaw JJ AND Dye C. 2002. Infectiousness in a Cohort of Brazilian dogs: why culling fails to control visceral leishmaniasis in areas of high transmission. J Inf Dis 186: 1314-1320.

da Silva VO, Borja-Cabrera GP, Correia Pontes NN, Paraguai de Souza E, Luz KG, Palatnik M and PalatniK-DE-Sousa CB. 2001. A Phase III trial of Efficacy of the FML-vaccine against canine kala-azar in an endemic area of Brazil (São Gonçalo do Amarante, RN). Vaccine 19: 1082-1092.

Dietze R, Baptista Barros G, Teixeira L, Harris J, Michelson K, FAlqueto A And Corey R. 1997. Effect of eliminating seropositive canines on the transmission of visceral leishmaniasis in Brazil. Clin Inf Dis 25: 1240-1242.
Dye C. 1996. The logic of visceral leishmaniasis control. Am J Trop Med Hyg 55: 125-130.

Evans TG, Vasconcelos IAB, Lima JW, Teixiera JM, Mc Aullife IT, Lopes UG, Pearson RD and VasCONCELOS A. 1990. Canine visceral leishmaniasis in northeast Brazil: assessment of serodiagnostic methods. Am J Trop Med Hyg 42: 118-123.

Furtado Vieira JB and Coelho EG. 1998. Leishmaniose visceral ou calazar: aspectos epidemiológicos e de controle. Rev Soc Bras Med Trop 31: 85-92.

Jeronimo SM, Teixeira MJ, Sousa AD, Thielking P, Pearson RD AND Evans TG. 2000. Natural history of Leishmania (Leishmania) chagasi infection in Northeastern Brazil: long-term follow-up. Clin Inf Dis 30: 608-609.

Machado Braga MD, Coelho ICB, Lima Pompeu M, Evans TG, Tavares MI, Teixeira MJ and Oliveira Lima J. 1998. Controle do calazar canino: comparação dos resultados de um programa de eliminação rápida de cães sororreagentes por ensaio imuno-enzimático com outro de eliminação tardia de cães sororreagentes por teste de imunofluorescência indireta de eluato de papel filtro. Rev Soc Bras Med Trop 31: 419-424.

Magalhães PA, Mayrink W, Costa CA, Melo MN, Dias M, Batista SM, Michalick MSM and WilLIAMs P. 1980. Calazar na zona do Rio Doce-Minas Gerais. Resultados de medidas profiláticas. Rev Inst Med Trop São Paulo 22: 197-202.

Mendes CO, Paraguai de Souza E, Borja-Cabrera GP, Melo Batista LM, Santos MA, Parra LE, Menz I and PalatniK-De-Sousa CB. 2003. IgG1/ IgG2 antibody dichotomy in sera of vaccinated or naturally infected dogs with visceral leishmaniasis. Vaccine 21/19-20: 2589-2597.

Nieto CG, Garcia Alonso M, Requena JM, Miron C, Soto M, Alonso C and Navarrete I. 1999. Analysis of the humoral response against total and recombinant antigens of Leishmania infantum: correlation with disease progression in canine experimental leishmaniasis. Vet Immunol Immunopathol 67: 117-130.

PalatniK-DE-Sousa CB. 2002. What is the potential use of serological tools in diagnosis of human kala-azar? (analysis of specificity, sensitivity and predictive values). Rev Soc Bras Med Trop 34: 55-57. 
PalatniK-De-Sousa CB, Gomes EM, Paraguai de Souza E, Palatnik M, Luz KG and Borojevic R. 1995. The fucose mannose ligand of Leishmania donovani in diagnosis and prognosis of visceral leishmaniasis (Kala-azar). Trans R Soc Trop Med Hyg 89: 390-393.

Palatnik-de-Sousa CB, Santos WR, França-Silva JC, Costa RT, Barbosa Reis A, Palatnik M, MayRINK W AND GENARO O. 2001. Impact of canine control on the epidemiology of canine and human visceral leishmaniasis in Brazil. Am J Trop Med Hyg. 65: 510-517.

Paranhos-Silva M, Freitas LA, Santos WC, Grimaldi JR G, Pontes de Carvalho L and Oliveira dos SAntos A. 1996. A cross-sectional serodiagnostic survey of canine leishmaniasis due to Leishmania chagasi. Am J Trop Med Hyg 55: 39-44.
Santana DM, Borja-Cabrera GP, Paraguai de Souza E, Sturm NR, Palatnik-de-Sousa CB AND CAmpbell DA. 2002. Nucleoside hydrolase from Leishmania (L.) donovani is an antigen diagnostic for visceral leishmaniasis. Mol Biochem Parasitol 120: 315-319.

Solano-Gallego L, Riera C, Roura X, Inieste L, Gallego M, Valladares Je, Fisa R, Castillejo AS, Alberola J, Ferrer L, Arboix M and Portus M. 2001. Leishmania infantum-specific IgG, IgG1 and IgG2 antibody responses in healthy and ill dogs from endemic areas. Evolution in the course of infection and after treatment. Vet Parasitol 96: 265-276.

Tesh R. 1995. Control of zoonotic visceral leishmaniasis. Is it time to change strategies? Am J Trop Med Hyg 52: 287-292. 